\title{
ANALISIS KEMAMPUAN BERPIKIR REFLEKTIF MATEMATIS BERDASARKAN MINAT BELAJAR PADA MATA KULIAH STRUKTUR ALJABAR
}

\author{
Yenni', Rika Sukmawati² \\ 1,2 Universitas Muhammadiyah Tangerang \\ email: yenni_aan@yahoo.co.id
}

\begin{abstract}
This study aims to describe the reflective thinking skills of mathematics education students in algebraic structure subjects based on their interest in learning. This reflective thinking ability is very important in maximizing learning outcomes. Included in this ability criterion is being able to use mathematical concepts in solving problems. This type of research is descriptive qualitative. The subjects of the study were the fourth semester students of the A2 class of the Mathematics Education Study Program FKIP Muhammadiyah University, Tangerang. Data collection techniques using tests, questionnaires and interviews. Analysis of the test results shows that students with high learning interest are able to master two indicators of reflective thinking ability well, as well as one other indicator that is imperfect. Students with moderate interest are only able to master one indicator of reflective thinking ability well, and two other indicators are not perfect. On the subject of this study, no students with low learning interest were found.
\end{abstract}

Keywords: Reflective thinking, interest in learning

\section{ABSTRAK}

Penelitian ini bertujuan untuk mendeskripsikan kemampuan berpikir reflektif mahasiswa pendidikan matematika pada mata kuliah struktur aljabar berdasarkan minat belajarnya. Kemampuan berpikir reflektif ini sangat penting dalam memaksimalkan hasil belajar. Yang termasuk dalam kriteria kemampuan ini adalah mampu menggunakan konsepkonsep matematika dalam menyelesaiakan masalah. Jenis penelitian yang digunakan adalah kualitatif deskripsif. Subjek penelitian adalah mahasiswa semester IV kelas A2 Program Studi Pendidikan Matematika FKIP Universitas Muhammadiyah Tangerang. Teknik pengumpulan data menggunakan tes, angket dan wawancara. Analisis hasil tes menunjukkan bahwa mahasiswa dengan minat belajar tinggi mampu menguasai dua indikator kemampuan berpikir reflektif dengan baik, serta satu indikator lain yang tidak sempurna. Mahasiswa dengan minat sedang hanya mampu menguasai satu indikator kemampuan berpikir reflektif dengan baik, serta dua indikator lain tidak sempurna. Pada subjek penelitian ini, tidak ditemukan mahasiswa dengan minat belajar rendah.

Kata Kunci: Berpikir reflektif, Minat belajar

Dikirim : 10 Juli 2019; Diterima : 27 September 2019; Dipublikasikan : 30 September 2019

Cara sitasi: Yenni, \& Sukmawati, R. (2019). Analisis kemampuan berpikir reflektif matematis berdasarkan minat belajar pada mata kuliah struktur aljabar. Teorema: Teori dan Riset Matematika, 4(2), 75-82. 


\section{PENDAHULUAN}

Telah disadari, tujuan mempelajari matematika sangat penting. Matematika sendiri memegang peranan penting dalam kehidupan sehari-hari. Salah satu sifat matematika yang abstrak, menjadi salah satu penyebab bagi mahasiswa mengalami kesulitan memahami konsep. Struktur aljabar adalah salah satu dari mata kuliah yang bersifat abstrak. Struktur aljabar merupakan salah satu mata kuliah yang wajib ditempuh bagi mahasiwa program studi pendidikan matematika pada Fakultas Keguruan dan IImu Pendidikan Universitas Muhammadiyah Tangerang.

Kemampuan dasar yang harus dimiliki mahasiswa agar mencapai hasil belajar yang maksimal pada mata kuliah struktur aljabar adalah memahami konsep, mampu mengaitkan antar konsep, serta kemampuan pembuktian. Kemampuan tersebut seharusnya sudah dimiliki mahasiswa saat mempelajari matematika pada sekolah menengah. Hal ini sesuai dengan tujuan mempelajari matematika secara umum pada sekolah tingkat menengah seperti yang dicantumkan oleh Permendiknas No 22 Tahun 2006, yaitu (1) memahami masalah; (2) merancang model matematika; (3) menyelesaikan model; (4) menafsirkan solusi yang diperoleh.

Sebagai akibat dari penguasaan indikator yang diterapkan oleh Permendiknas No 22 tersebut, diharapkan dapat membentuk kemampuan berpikir kritis, kreatif dan reflektif. Hal senada diungkapkan oleh Jaenudin, Nindiasari dan Pamungkas (2017) bahwa kegiatan belajar yang menekankan pada proses belajar akan menghadirkan kegiatan berpikir dalam berbagai bentuk. Kaitan dengan penelitian ini, bahwa perlu diketahui apa yang dimiliki oleh mahasiswa setelah mereka belajar struktur aljabar. Sehingga pengajar dapat mengetahui bahwa apa yang disampaikan telah sampai ke mahasiswa sesuai rencana pembelajaran.

Berpikir reflektif merupakan salah satu penentu dalam keberhasilan belajar (Supriyaningsih dkk, 2017). Sejalan dengan pendapat Subandar (2009) bahwa dalam mempelajari matematika siswa harus dapat berpikir agar mampu memahami dan menggunakan konsep-konsep matematika secara tepat dalam meyelesaikan masalah matematika. Proses berpikir yang dimaksudkan oleh Sabandar adalah berpikir reflektif, karena yang dimaksud dengan berpikir reflektif adalah berpikir yang bermakna, yang berdasarkan pada alasan dan tujuan. Berpikir reflektif merupakan jenis pemikiran yang melibatkan pemecahan masalah, perumusan kesimpulan, memperhitungkan hal-hal yang berkaitan, dan membuat keputusan-keputusan di saat seseorang menggunakan keterampilan yang bermakna dan efektif untuk konteks tertentu dan jenis dari tugas berpikir (Haryati dkk, 2017)

Suharya (2012) menyatakan bahwa pemikiran reflektif merupakan kesadaran tentang apa yang diketahui dan apa yang dibutuhkan, hal ini sangat penting untuk menjembatani kesenjangan situasi belajar. Pada kasus mempelajarai materi struktur aljabar yang bersifat abstrak, tentu saja hal ini menjadi sangat penting. Kesadaran bahwa individu telah paham, telah menguasai bahasan, dan mampu menggunakan ilmunya untuk pembuktian harus dimilki oleh mahasiswa. Kesadaran berpikir dalam diri dapat menuntun melakukan tugas-tugas khusus, dan mengontrol apa yang akan dikerjakan (Zakiah, 2017a). Jika hal tersebut telah dimiliki oleh mahasiswa secara sadar, tentu mampu mendapat hasil maksimal pada mata kuliah struktur aljabar. Dengan demikian dorongan dalam diri mahasiswa menjadi lebih besar untuk mempelajari lebih lanjut.

Indikator kemampuan berpikir reflektif menurut Nindiasari dkk (2013) adalah: (1) dapat mengidentifikasikan konsep dan atau rumus matematika yang terlibat dalam soal matematika yang tidak sederhana; (2) dapat mengevaluasi/memeriksa kebenaran suatu argumen berdasarkan konsep/sifat yang digunakan; (3) dapat menarik analogi dari dua kasus serupa; (4) dapat menggeneralisasi disertai alasan; (5) dapat membedakan antara data yang relevan dan tidak relevan dan (6) dapat menginterpretasi suatu kasus berdasarkan konsep matematika yang terlibat. Sedangkan Zulmaulida (2012) mendefinisikan berpikir reflektif sebagai suatu kegiatan berpikir yang dapat membuat siswa berusaha menghubungkan pengetahuan yang diperolehnya untuk menyelesaikan permasalahan baru yang berkaitan dengan pengetahuan lamanya. Berpikir reflektif terjadi saat para siswa mencoba memahami penjelasan dari orang lain, ketika mereka bertanya, dan ketika mereka menjelaskan atau menyelidiki kebenaran ide mereka sendiri. 
Pada penelitian ini, indikator berpikir reflektif dibatasi pada: (1) dapat mengevaluasi/ memeriksa kebenaran suatu argumen berdasarkan konsep/sifat yang digunakan; (2) dapat menggeneralisasi disertai alasan; dan (3) dapat menginterpretasi suatu kasus berdasarkan konsep matematika yang terlibat. Alasan pemilihan indikator karena disesuaikan dengan materi mata kuliah struktur aljabar yang diteskan.

Lebih lanjut, Gurol (2011) mendefinisikan berpikir reflektif sebagai proses kegiatan terarah dan tepat dimana individu pembelajar menyadari untuk diikuti, menganalisis, mengevaluasi, memotivasi, mendapatkan makna yang mendalam, menggunakan strategi pembelajaran yang tepat. Hal ini sesuai dengan apa yang dilakukan oleh peneliti. Bahwa peneliti bertujuan agar pembelajaran struktur aljabar lebih bermakna tanpa terkesan memaksa mahasiswa untuk menghafal materi. Karenanya diperlukan suatu formula yang dapat digunakan sebagai energi tambahan dalam menaikkan keinginan belajar.

Selain dari aspek pembelajaran, terdapat aspek penting yang lain yang harus diperhatikan oleh pendidik (Zakiah, 2017b). Adanya dorongan untuk belajar matematika diistilahkan sebagai minat. Minat belajar diartikan sebagai suatu kecenderungan pada suatu hal, sehingga memiliki dorongan secara suka rela terhadap kegiatan yang berkaitan dengan sesuatu tersebut. Menumbuhkan minat belajar ini menjadi sangat penting karena berhubungan dengan tindak lanjut selanjutnya. Minat yang tinggi diprediksi akan membuat seseorang semakin rajin melakukan sesuatu sehingga hasil kegiatan semakin bermakna. Dalam proses belajar mengajar matematika minat belajar sangat besar peranannya. Hidayullahlathifah dan Sujadi (2017) menegaskan, bahwa minat belajar sangat besar peranannya terhadap prestasi belajar. Namun, permasalahan minat belajar ternyata menjadi salah satu faktor penghambat dalam belajar. Minat belajar yang kurang tentu akan menyebabkan rasa malas pada individu untuk mencapai hasil berlajar yang maksimal. Ini menjadi perhatian tersendiri dimana masalah minat belajar, khususnya pada bidang matematika telah terjadi sejak tingkat sekolah dasar. Hal ini ungkapkan oleh Fifko (2017), kasus pada SD Negeri Kotagede I Yogyakarta ditemukan bahwa pada kenyatannya, khususnya pada pelajaran matematika masih sering dijumpai permasalahan kurangnya minat belajar siswa dan rendahnya aktivitas belajar siswa. Tentunya, hal tersebut harus segera ditangani, agar tidak merembet ke tingkat yang lebih tinggi

Pada penelitian ini, minat bertujuan untuk memaksimalkan hasil belajar mata kuliah struktur aljabar. Dengan demikian mahasiswa lebih fokus dan perhatian terhadap struktur aljabar. Pendapat serupa diungkapkan oleh Silviani dkk (2017), bahwa minat merupakan rasa ingin tahu atau daya tarik seseorang terhadap sesuatu yang melibatkan perhatian terhadap objek tertentu. Objek yang dimaksud tersebut adalah kemampuan berpikir reflektif mahasiswa.

\section{METODE PENELITIAN}

Penelitian ini merupakan penelitian kualitatif jenis deskripstif dengan tujuan mendeskripsikan kemampuan reflektif matematis pada mata kuliah struktur aljabar berdasarkan minat belajar mahasiswa. Minat belajar mahasiswa selanjutnya digolongkan menjadi tiga tingkatan, yaitu minat belajar tinggi, sedang dan rendah.

Subjek penelitian adalah mahasiswa pendidikan Program Studi Pendidikan Matematika Fakultas Keguruan dan IImu Pendidikan Universitas Muhammadiyah Tangerang pada Tahun Akademik 2017/2018. Sampel dipilih secara purposive dengan tujuan agar memaksimalkan hasil penelitian, yaitu mahasiswa semester IV kelas A2 yang berjumlah 24 mahasiswa.

Teknik pengumpulan data dengan menggunakan tes, angket dan wawancara. Tes berupa soal essay yang memuat indikator kemampuan reflektif. Data kemampuan reflektif diperoleh dengan cara memberikan soal struktur aljabar kepada mahasiswa. Selanjutnya, hasil pekerjaan siswa diperiksa dan dianalisis. Instrumen tes kemampuan reflektif terdiri dari tiga soal. Masing-masing satu soal mewakili indikator kemampuan berpikir reflektif. Setiap satu soal diberikan skor 25 . Dengan demikian maksimal skor adalah 75 . 
Nilai tes kemampuan reflektif selanjutnya di kategorikan menjadi lima level, yaitu $A, B C, D$ dan E. Tabel rentang penilian didasarkan pada panduan penilaian FKIP UMT sebagai berikut:

\begin{tabular}{cc}
\multicolumn{2}{c}{ Tabel 1. Interval dan nilai mutu } \\
\hline Interval & Keterangan \\
\hline $80-100$ & $\mathrm{~A}$ \\
$68-79$ & $\mathrm{~B}$ \\
$56-67$ & $\mathrm{C}$ \\
$45-55$ & $\mathrm{D}$ \\
$<44$ & $\mathrm{E}$ \\
\hline
\end{tabular}

Instrumen angket diberikan untuk menghimpun data minat belajar mahasiswa. Intrumen angket berupa pernyataan. Indikator minat belajar mahasiswa dibagi menjadi 4, yaitu perasaan senang sebanyak 6 pernyataan, perhatian sebanyak 9 pernyataan, ketertarikan sebanyak 7 pernyataan dan keterlibatan mahasiswa sebanyak 5 pernyataan. Angket minat belajar matematika berjumlah 27 pernyataan dengan 4 pilihan jawaban, yaitu selalu (SL), sering (SR), kadang-kadang (KD), tidak pernah (TP). Besar skor untuk SL, SR, KD, TP berturut-turut adalah 4, 3, 2, 1 untuk pernyataan positif. Sedangkan skor untuk pernyataan negatif adalah 1, 2, 3, 4. Selanjutnya, minat belajar akan dibagi menjadi tiga tingkatan yaitu tinggi, sedang, dan rendah.

Berdasarkan jumlah pernyataan angket, maka skor minimum 27, skor maksimum 108. Rentang 81. Interval $81 / 3=27$. Dengan demikian, level minat belajar struktur aljabar diinterpretasikan sebagai berikut:

\begin{tabular}{|c|c|}
\hline Klasifikasi minat belajar & Interval \\
\hline Rendah & $27-53$ \\
\hline Sedang & $54-80$ \\
\hline Tinggi & $81-108$ \\
\hline
\end{tabular}

Angket wawancara disiapkan untuk menghimpun data dan pendapat mahasiswa yang tidak tergambar pada tes uraian dan angket minat belajar mahasiwa. Diharapkan, data lebih mendalam tentang kemampuan reflektif dan minat belajar pada struktur alajabar. Jenis wawancara yang digunakan dalam penelitian ini adalah wawancara tidak terstruktur. Pertanyaan-pertanyaan yang diberikan kepada mahasiswa berupa garis-garis besar permasalahan pada cara mahasiswa menjawab soal struktur aljabar dan poin-poin yang mengarah pada minat belajar mahasiwa.

Sebelum digunakan, instrumen tes kemampuan berpikir reflektif, angket minat belajar, dan daftar pertanyaan wawancara telah divalidasi dan telah mendapatkan pernyataan layak untuk dipergunakan.

\section{HASIL DAN PEMBAHASAN}

Indikator kemampuan berpikir reflektif yang digunakan dalam penelitian ini sebanyak tiga indikator. Berikut adalah soal yang mewakili masing-masing indicator.

Tabel 3. Indikator dan instrumen berpikir reflektif

\begin{tabular}{ll}
\hline \multicolumn{1}{c}{ Indikator berpikir reflektif } & \multicolumn{1}{c}{ Soal } \\
\hline Dapat mengevaluasi/memeriksa & Himpunan semua bilangan bulat modulo 12 yaitu $Z_{12}$ terhadap operasi \\
kebenaran suatu argumen & penjumlahan pada bilangan modulo 12 merupakan grup siklis. \\
berdasarkan konsep/sifat yang & a. Tentukan generator dari grup siklis tersebut! \\
digunakan & b. Sebutkan salah satu subrup dari $(Z,+12)$. \\
& c. Berdasarkan subgrup yang Anda contohkan, apakah subgrup tersebut \\
& merupakan subgrup siklis? Buktikan!
\end{tabular}


Dapat menggeneralisasi disertai alasan

Dapat menginterpretasi suatu kasus berdasarkan konsep matematika yang terlibat
Misalkan $B=\{x \mid x$ adalah bilangan bulat $\}$ dan $G=\left\{2^{x} \mid x \in Z\right.$ ). Selidiki, apakah $f: Z \rightarrow G$, dengan $(Z,+)$ dan $(G, x)$ isomorfik?

$(R,+, x)$ didefinisikan dengan operasi penjumlahan dan perkalian. $(Z,+)$ didefinisikan dengan $a+b=a+b-a b$ dan $a \times b=a+b+1$. Tunjukkan apakah $(R,+, x)$ merupakan ring komutatif?

Berdasarkan hasil pekerjaan mahasiswa dalam menyelesaikan soal kemampuan berpikir reflektif diperoleh data sebagai berikut:

Tabel 4. Skor kemampuan berpikir reflektif

\begin{tabular}{ccc}
\hline Keterangan & Skor & Nilai \\
\hline Maksimal & 68 & 90,67 \\
Minimal & 42 & 56 \\
Rata-rata & 53,04 & 70,72 \\
\hline
\end{tabular}

Hasil tes menunjukkan 16,67\% mahasiswa memperoleh nilai A, 45,83\% memperoleh nilai $B$, dan $37,5 \%$ memperoleh nilai $C$. Tidak terdapat mahasiswa dengan nilai $D$ atau $E$. Lebih lengkap diberikan pada tabel berikut.

Tabel 5. Skor kemampuan berpikir reflektif

\begin{tabular}{ccc}
\hline Kriteria & Jumlah mahasiswa & Persentase \\
\hline A & 4 & 16,67 \\
B & 11 & 45,83 \\
C & 9 & 37,5 \\
D & 0 & 0 \\
E & 0 & 0 \\
\hline
\end{tabular}

Selanjutnya, akan disajikan rekap skor minat belajar siswa sebagai berikut.

Tabel 6. Skor minat belajar matematika

\begin{tabular}{cc}
\hline Keterangan & Skor \\
\hline Maksimal & 87 \\
Minimal & 55 \\
Rata-rata & 74,125 \\
\hline
\end{tabular}

Berdasarkan kriteria minat yang telah disusun terdapat $87,5 \%$ mahasiswa memiliki minat belajar sedang, dan $12,5 \%$ memiliki minat tinggi. Tidak terdapat mahasiswa dengan minat belajar rendah. Lebih lengkap disajikan dalam tabel beikut.

\begin{tabular}{ccc} 
Tabel 7. Rekap minat belajar mahasiswa terhadap struktur aljabar \\
\cline { 2 - 3 } Kriteria & Jumlah mahasiswa & Persentase \\
\hline Rendah & 0 & 0 \\
Sedang & 21 & 87,5 \\
Tinggi & 3 & 12,5 \\
\hline
\end{tabular}

Pengumpulan data terakhir yaitu dengan wawancara. Untuk keperluan ini, diambil dua subjek dengan cara purposive. Satu mahasiswa mewakili mahasiswa dengan minat belajar tinggi, dan satu mahasiswa lainnya mewakili mahasiswa dengan minat belajar sedang.

Mahasiswa dengan minat belajar tinggi dipilih dengan ketentuan memiliki skor minat belajar tertinggi, yaitu 87. Nilai tes kemampuan berpikir reflektif yang dicapai adalalah 68 . Jadi, subjek 
adalah pemilik skor minat belajar dan hasil tes tertinggi. Subjek dapat menyelesaikan indikator menggeneralisasi disertai alasan dan menginterpretasikan suatu kasus berdasarkan konsep matematika yang terlibat dengan baik. Jawaban yang diberikan sesuai dengan ketentuan. Namun, untuk indikator pertama, pada pertanyaan c subjek tidak menguraikan alasan kenapa subgroup yang dicontohkan adalah grup siklis. Subjek dengan minat tinggi mengatakan waktu yang diberikan kurang. Waktu yang diberikan adalah 45 menit untuk tiga soal.

Subjek mahasiswa dengan minat belajar sedang dipilih dengan memilih salah satu dari 21 mahasiswa yang memiliki skor minat belajar sedang. Subjek mampu menyelesaikan dengan baik indikator mengevaluasi/memeriksa kebenaran suatu argumen berdasarkan konsep/sifat yang digunakan. Jawaban yang diberikan sesuai dengan yang seharusnya. Namun, pada dua indikator lain, subjek ini memberikan jawaban yang tidak sempurna. Pada indikator menggeneralisasi disertai alasan, subjek menjawab salah pada saat menguraikan syarat isomorfik. Akibatnya jawaban akhir salah. Sedangkan pada indikator menginterpretasikan suatu kasus, subjek hanya mengurai syarat $(R,+)$. Alasan yang diberikan sama dengan dengan subjek minat belajar tinggi, yaitu waktu yang diberikan kurang.

\section{KESIMPULAN}

Berdasarkan analisis hasil tes menunjukkan bahwa mahasiswa dengan minat belajar tinggi mampu menguasai dua indikator kemampuan berpikir reflektif dengan baik, serta satu indikator lain yang tidak sempurna. Mahasiswa dengan minat sedang hanya mampu menguasai satu indikator kemampuan berpikir reflektif dengan baik, serta dua indikator lain tidak sempurna. Pada subjek penelitian ini, tidak ditemukan mahasiswa dengan minat belajar rendah.

\section{REKOMENDASI}

Beberapa hal yang dapat direkomendasikan berdasarkan hasil penelitian ini yaitu bahwa pengajar struktur aljabar harus memberikan latihan berupa kesempatan bagi mahasiswa untuk menerangkan. Hal ini dapat dilakukan dengan menerangkan jawaban dari soal latihan yang dikerjakan atau materi. Ini berakibat waktu di kelas yang kurang. Hal ini dapat disiasati dengan mengemas bahan ajar, serta memberikan tugas rumah untuk pendalaman materi.

\section{UCAPAN TERIMAKASIH}

Terimakasih pada Dian Nopitasari, M. Pd., Abdul Baist, M. Si., Eka Rachma Kurniasai, M.Pd., yang telah membantu memvalidasi instrumen pada penelitian ini.

\section{DAFTAR PUSTAKA}

Fifko, H. (2017). Meningkatkan minat belajar matematika melalui media dekak multifungsi di Sekolah Dasar. Jurnal Pendidikan Guru Sekolah Dasar, Edisi 3 Tahun ke 6.-6: 215-221.

Gurol, A. (2011). Determining the reflective thinking skills of pre-service teachers in learning and teaching process. Energy Education Science and Technology Part B: Social and Educational Studies, 3(3), 387-402.

Haryati, T., Nindiasari, H., \& Sudiana, R. (2017). Analisis kemampuan dan disposisi berpikir reflektif matematis siswa ditinjau dari gaya belajar. Jurnal Penelitian dan Pembelajaran Matematika, $10(2), 146-158$.

Hidayatullahlathifah, \& Sujadi, A. A. (2017). Peningkatan minat dan prestasi belajar matematika melalui pembelajaran make a match siswa kelas VIIF SMP 1 Banguntapan. Jurnal Pendidikan Matematika, 5(3), 229-236. 
Jaenudin, Nindiasari, H., \& Pamungkas A. S. (2017). Analisis kemampuan berpikir reflektif matematis siswa ditinjau dari gaya belajar. Jurnal Pendidikan Matematika, 1(1), 69-82.

Nindiasari, H., Kusumah, Y. S., Sumarmo, U., Sabandar, J., dkk. (2014). Pendekatan metakognitif untuk meningkatkan kemampuan berpikir reflektif matematis siswa SMA. Jurnal IImu Pendidikan dan Pengajaran, 1(1), 1-12.

Sabandar, J. (2009). Berpikir reflektif dalam pembelajaran matematika. UPI: Himpunan Matematika Indonesia, 1(1). [Online]. Tersedia: http://fmipa.um.ac.id, [15 Maret 2017]

Silviani, T. R., Jailani, Lusyana, E., \& Hadi, A. R. (2017). Upaya meningkatkan minat belajar matematika menggunakan inquiry based learning setting group investigation. Jurnal Matematika Kreatif Inovatif, 8(2), 150-161.

Suharya, H. (2012). Berpikir reflektif (reflective thinking) siswa SD berkemampuan matematika tinggi dalam pemahaman masalah pecahan. Prosiding pada Seminar Nasional Matematika dan Pendidikan Matematika FMIPA UNY. 10 November 2012, Universitas Negeri Yogyakarta.

Supriyaningsih, N., Kriswandani, \& Prihatnani, E. (2017). Profil kemampuan berpikir reflektif Siswa SMP dalam menyelesaiakan soal matematika PISA pada konten quantity. Prosiding Seminar Nasional Etnomatnesia. 29 November 2017. Universitas Sarjanawiyata Tamansiswa.

Zakiah, N. E. (2017a). Pembelajaran dengan pendekatan kontekstual berbasis gaya kognitif untuk meningkatkan self awareness siswa. Teorema: Teori dan Riset Matematika 2(1), 11-20. http://dx.doi.org/10.25157/teorema.v2i1

Zakiah, N. E. (2017a). Pembelajaran dengan pendekatan kontekstual berbasis gaya kognitif untuk meningkatkan kemampuan metakognitif siswa. Pedagogy 2(2), 11-29. https://journal.uncp.ac.id/index.php/Pedagogy/article/view/700

Zulmaulida, R. (2012). Pengaruh pembelajaran dengan pendekatan proses berpikir reflektif terhadap peningkatan kemampuan konesi dan berpikir kritis matematis siswa. Tesis. Universitas Pendidikan Indonesia Bandung: Tidak dipublikasikan. 
•82 Teorema: Teori dan Riset Matematika, 4(2), 75-82, September 2019 